\title{
The Possibility of Knowledge Sharing Not Affected To Innovation Aptitude: A Study of Home Industries In North Sulawesi Province Indonesia
}

\author{
Ventje A. Senduk ${ }^{1}$ \\ ${ }^{I}$ (Faculty of Economy/ Manado State University, Manado, Indonesia)
}

\begin{abstract}
This article divided into several section whereas section introduction, section covers theory, previous research and developing research hypothesis, section research method, section contains research results and discussion. The researches was conducted in North Sulawesi due to its fascinating development. This research uses an explanatory research design by applying a survey approach. This method enables research findings to be generalized across persons, settings, and time. Selected respondents are invited respondent for sake of suceeding this research. Invited respondent as many as 300 home industry owners or manager from several home industry in Manado city and Minahasa county. From 300 phase one survey invitations only 207 invitation attended and asked to fill in the provided questionnaire sheet. Then second phase survey sent to 207 invitation attended in phase one and only 123 attended. Data collection and compiling report also article writing in this research costs one and a half year, from March 2012 till August 2013. The resuls show that all hypothesis that testing are accepted. This research result can also be interpreted to confirm the results of research which contradicts copy that has been described in the previous section.
\end{abstract}

Keywords: Innovation Aptitude, Knowledge Sharing, Home Industry

\section{INTRODUCTION}

Undisputedly in free information era we are having today creates an altering in business ground atmosphere with high altitude of competitive level. Even business paradigm nowadays has shifted from economic basis into knowledge and information basis paradigm. This paradigm shift facilitates high altitude of competitive level business based on excellent knowledge management (Wuryaningrat, 2012). Innovation is one of the options taken by companies to reinforce their competitive issue and mostly became major key point of the company business success. (Johannesen et al., 2001; Nonaka and Takeuchi, 1995).

The company innovation capability is highly depends on knowledge resources which is why the opulence of company innovation needs to be neatly organized and valued in order to guarantee company success enhancing their competitiveness by innovation (Du Plessis, 2007). An innovative company is a company with capability of handling and organizing knowledge effectively (Darroch, 2005). In other word, an effective and excellent system utilizing opulence of knowledge resources defined as an effort made by the company for enhancing its capability in term of competitiveness by increasing knowledge opulence resources. According to Davenport and Prusak (1998), knowledge resources has its own uniqueness compare to other resources. Uniqueness refers by Davenport and Prusak, (1998) is the continuity development of knowledge resources as their being utilized.

One of the way large and small companies for utilizing their knowledge resources is by knowledge sharing. Knowledge sharing became inseparable element from company because according Argote et al. (2003) knowledge sharing is a way how company optimize knowledge resources.

Research result conducted by Lin (2007) reveals that by utilizing knowledge sharing, company knowledge resources can be enriched continuously for innovation creation (Lin, 2007). The reasoning revealed by Lin (2007) is knowledge sharing possess the capability regenerating a brand new knowledge which this new knowledge hopefully can be utilized for upgrading innovation aptitude. Another study conducted by Miller et al. (2007, in Wuryaningrat, 2012) produce an empirical evidence of knowledge sharing between divisions in the company are truly helpful in regenerating innovation. Dyer and Nobeoko (2000) stated that Toyota became a successful business company and became role model by other company is by sharing knowledge with their suppliers. Furthermore explained, knowledge sharing conducted by Toyota itself allows Just in Time (JIT) effectively performed. The research conducted by Darroch (2005) also fortifies opinion knowledge sharing inside an organization has a positive effect to innovation aptitude of the company.

However, one of researches conducted by Wuryaningrat (2012) about SMIs/SMEs in Special Territory of Yogyakarta Province reveals the contrary. The result emerge a possibility of knowledge sharing given a negative effect if not support by adequate personal absorptive capability. Liao et al. (2006) disclose in its research about knowledge sharing happen to be incapable affecting innovation of the company without fine 
absorptive capacity support. The result of this research surely differs from other research. Therefore it is important to point out the importance of replicate or readopting those other research result since it has relation with external validity of previous research. In brief way, the research of Wuryaningrat (2012) and Liao et al. (2006) needed to adopt and redeveloped for generating more information about how sharing knowledge affects the company. Research being carries out in smaller scale business or so called home industry. Wuryaningrat (2012) explains about weakness factor of SMIs/SMEs which composes negative effect of sharing knowledge possible to innovation aptitude of small and middle class industries/enterprises or SMIs/SMEs. For that kind reason, Home industry is eligible as research specimen. Home industry is limited to small scale business. Home industry also had characteristically resemblance with SMIs/SMEs therefore all deficiency occurs in SMIs/SMEs also persist in home industry.

This article divided into few section whereas the first section is introduction of problem which reveals the motive of importance why this research being present. Second section covers theory, previous research and developing research hypothesis. Third section point out about selected research method. Fourth section contains research and discussion result which also covers validity, reliability and hypothetical test. In this section also reveal discussion in research. the last section concluded by the research limitation and further research suggestion.

\section{FUNDAMENTAL THEORIES}

\subsection{Innovation and Innovation Funnel}

Innovation in open information era nowadays supposed to be part daily life of the company to materialize continuation of competitive aptitude. Innovation as continuation of competitive aptitude can be referring to key of company success (Nonaka dan Takeuchi, 1995). Company either large or small needs innovation, according to admitted opinion, Tidd et al. (2005) states that innovation became necessity needs for company either large or small for competition survival.

In acquiring competitive aptitude, company required strategic dominance which acknowledged by innovative company. This opinion agreed by Schumpeter (in Tidd et al., 2005) which implies that innovation is inseparable from entrepreneurship spirit that keep on seeking innovative way acquiring strategic dominance. Innovation nowadays already considered as fundamental aspect of entrepreneurship and key element for business success (Pirich et al., 2001; Covin dan Miles, 1999).

Definition of innovation can be diverse but can be put into one conclusion which is innovation as form of newest. Johannessen et al. (2001 in Wuryaningrat, 2012) states an opinion which defined innovation as form of newest aimed to create and maintain continuation of competitive aptitude. Innovation meant by Johannessen et al. (2001, in Wuryaningrat, 2012) affix with product innovation, service innovation, new production innovation method, new market innovation method, new supply resources innovation, and new way of operation system innovation.

Innovation as form of newest closely related to where it being adopted, which means innovation as form of newest in perception scope of its creator (company) (Tidd et al., 2005). As for example, SMIs/SMEs applies email usage as part of communication facility, this change might be something new for the company and creating potential conflict or new problem into the company. However, in large company this issue became a common sense.

Ki Hajar Dewantara, one of Indonesia's historical figures in education aspect also develops definition of Innovation. Ki Hajar Dewantara stated that innovation consist of 3N; Ngamati, Niroke, Ngembangke. With more understandable language, innovation started with observation then immitate and for final act, developing the already imitated. As for example, China is an impersonator country that nowadays developed into an innovative country also one of the biggest country in the world. Further back, Japan also takes the same path and became advance country after learning greatly from superpower country, United States.

Eventhough innovation is a necessity to small and large company, the application however need extra effort from company. This extra effort can conclude adjustment change in all element of company. Innovation needs adjustment because its application might emerge pro and contra for requirable changes. Those who pro of innovation might realized the importance for the company and people inside the organization to be adaptable and follow the innovation changes of the company. As for those who contra, it might be caused by incapability of them absorbing current knowledge to keep on track company innovation.

Lack of acquired knowledge to keep on track company innovation can be explained by using innovation funnel theory and concept (Clark and Wheelright, 1992). Theory which assumed that mass number of knowledge, information, and ideas received by somebody could create a confusing and dificulty state on determining relevant knowledge for regenerating innovation.

Innovation funnel concept illustrate similarly as pouring too much water into funnel, therefore it will spill out and became waste. From such illustration, the probability that gathering knowledge which became 
frequent activity can generate new unusable knowledge and because of that innovation aptitude weaken instead of increasing.

\subsection{Knowledge Sharing}

Nonaka et al. (2006) defines creation of knowledge by knowledge sharing through a continuous learning process of acqusition new context, new point of view and new knowledge. Such continuous learning process has more value if the already learned knowledge by individual being shared among others instead being reserved for self-sake.

Knowledge sharing inside the organization may be defined as knowledge trading process either tacit or explicit for sake of regenerating new knowledge (Van den Hoof and Ridder, 2004). Appearance of knowledge sharing according to Bartol and Srivastava (2002) is an individual capable and willingly provide ideas, suggestion, advice, information, experience, and expertise to other team member inside the organization. According to Van den Hoof and Ridder (2004) knowledge sharing divided into two different dimension namely knowledge collecting and knowledge donating.

Knowledge sharing became key success on translating process of individual learning to achieve an organizational capability (Frey and Oberholzer-Gee, 1997; Nahapiet and Ghoshal, 1998; in Lam and Lambermont-Ford, 2008). However, Lam and Lambermont-Ford (2008) reminds that knowledge sharing process is not easy to conduct as it highly depends on individual willingness for sharing. Such complication by Szulanski (1996, 2000) regarded as stickiness of knowledge because its a social process who posses complexity difficultness and causal ambiguity. Further difficulty is not all individual achieve an equal absorptive capacity to digest knowledge. While absorptive capacity is an absolute component in knowledge sharing (Davenport and Prusak, 1998).

\subsection{Review of Previous Research}

In knowledge management context as one of new science ground in knowledge sharing inside the organization was a pertinent element on optimalized knowledge resources (Bartol and Srivastava, 2002). Knowledge sharing obtain an ability for regenerating new knowledge which hopefully can be utilized for upgrading innovation ability. This issue was an argument revealed in previous research. Research performed by Miller et al. (2007 in Wuryaningrat, 2012) enlight us with an understanding which proven emphirically by sharing knowledge interdivisional inside a company facilitate them to ignite changes or rejuvinate.

Qualitative research with study case method conducted by Dyer and Nobeoko (2000) presented a knowledge about the reason why Toyota became one of world's big automotive industry. Dyer and Nobeoko (2000) points out how Toyota advanced through knowledge sharing conducted between producer and supplier of Toyota in Japan. Result of their knowledge sharing had suceed to create an increasing cost efficiency and product dissimilarization. According to study conceded by Lin (2007) reveals that large and small industry had demonstrated increase its innovation capability via sharing knowledge. Darroch (2005) added that the distribution of knowledge through knowledge sharing between individual within organization also take part in affecting innovations of the company.

In Indonesia, such research had been started with ther result of not so differ from already explained research result on previous pharagraph (See Indarti, 2010). However, the most interesting here here are research from Wuryaningrat (2012) and Liao et al. (2006) which generate totally different result. Through Wuryaningrat (2012) research we acknowledge that knowledge sharing bring negative effect on innovation aptitude of SMIs/SMEs in Special Territory of Yogyakarta Province. Furthermore revealed key weaknesses from SMIs/SMEs such as inadequate funds, meager information and market acess dan less accomplished workforce. these are the setbacks which create a contradiction result with other research. Liao et al. (2006) explains that without adequate absorptive capacity, knowledge sharing will not affecting company.

\subsection{Hypotesis Development: Home Industry and Innovation}

Home industry is a small scale business. According to North Sulawesi Statistical Bureau called Badan Pusat Statistik (BPS), home industry is a bussiness with number of employees less than five persons. The advantage of less employees itself allows home industry bussiness performing knowledge sharing. According Davenport and Prusak (1998) numbers of employee also affecting process of knowledge sharing inside the company.

Home industry is similar to other middle class small industry and generally have several common flaws such as less fund including initial knowledge, lesser amount of capable workforce and meager attention from government. These weaknesses make the frequent knowledge sharing performed by them into a questionable state of result or still not the obtain preferred result. The research result from Wuryaningrat (2012) disclose that knowledge sharing in fact have weakening effect on middle class small industry in term of innovation aptitude. Eventhough being contrastive from previous researches (see Introduction section) however, the result of this 
research became something usual considering the weaknesses which has previously explained. As for example, funding often make home industry business delay even halted their effort for trying or innovating, although receiving so many input from every side. Several report result from mass media and research unveil home industry flaw on innovating. In Simalungan county of North Sumatra, home industry product unable to compete with others in terms of attracting public buying interest because of its lack creativity on product packing (Metro Siantar, 10 April 2013).

Production of roasted coating peanut "Ohara" in central Sulawesi still stalled with very traditional production process and limited to consumer demand also setback on supply (Mas et al., 2013).

Aside from already mentioning above, home industry had other setbacks such as far from market access and access to information (Vinding, 2000 in Wuryaningrat, 2012). For that reason, home industry probably uncapable to capitalized its innovation aptitude. Eventhough sometimes posses new products or new production process. However, it appears that their products more on imitating phase from alerady exist products or just a tag along behaviour. An observation result has been conducted in peanut snacks home industry society situated in Kawangkoan district Minahasa, Indonesia founded that their products are less innovative (Senduk, 2011). Less innovative here means their new produced product solely result from imitating process with few improvement beforehand, not forget to mention their production method also less develop.

In this research also suspect that knowledge sharing practiced by home industry not yet capable generate innovation. In other word, innovation aptitude not always available for developing by knowledge sharing. Eventhough still needed and consider to be useful but in short term utility not giving any significant result. As do so, length of constant learning time is highly advised like the essence of knowledge sharing which is learning process from others (Nonaka et al., 2006).

Presentation result then being sum up into first hypothesis one (1a and $1 \mathrm{~b})$ which is: Knowledge sharing (a. Knowledge collecting, $b$. knowledge donating) unable to contribute significant effect to innovation aptitude of home industry.

However, knowledge sharing can be trusted when observing result from other research will give positive effect even conducted in continous way and recurrent. If knowledge sharing at present still unsucessful, hopefully it will change its fortune in near future. Knowledge is an unique resources because it can be upgraded according to the way it utilize (Davenport and Prusak, 1998). By that, throughout slower learning process it's possible that knowledge sharing can benefit to upgrading innovation aptitude of home industry. Liao et al, 2006 reveals that knowledge sharing as a learning process that can be used to increase absorptive capacity and when absorptive capacity on better state so does innovation aptitude.

This presentation result then being consider as hypothesis two (2a and $2 \mathrm{~b}$ ), which is: Knowledge sharing ( $a$. Knowledge collecting, $b$. knowledge donating) were positively affected on innovation aptitude of home industry.

\subsection{Research Model}

Based on the discussion about theory and hypothesis development that has been described previously, one research model can be seen in Figure below.

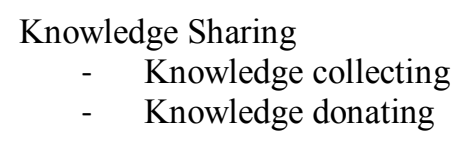

Innovation Capabilities

\subsection{Method}

\section{RESEARCH METHODS}

The researches was conducted in North Sulawesi due to its fascinating development. North Sulawesi is regarded as one of the regions experiencing the highest economic growth.' According to data gained from North Sulawesi Statistical Bureau, the economic growth in North Sulawesi during the first semester of 2012 has increased by 7.49 percent if compared to the first semester of 2011. The economic growth of North Sulawesi economy is even higher than Indonesia's economy growth which is only 6.3 percent (Wuryaningrat, 2012).

The cultural uniqueness of North Sulawesi, sitou tumou tou, which means "sharing, giving respect to others, and giving help", makes this area become an interesting topic to explore. Davenport and Prusak (1998) explain that the cultural similarities play an important role in encouraging a person to share knowledge.

This research uses an explanatory research design by applying a survey approach. This method enables research findings to be generalized across persons, settings, and time (Cooper and Schlinder 2008). However, this research faces obstacles because the data gained from SMEs agencies of North Sulawesi Province do not reflect the reality. Therefore, to gain more credible data, this research involves non random sampling techniques. 
Selected respondents are invited respondent for sake of suceeding this research. Invited respondent as many as 300 home industry owners or manager from several home industry in Manado city and Minahasa county. These two places being selected because of teritorial vastness in North Sulawesi province and by that reason these two worthed being selected for representing the whole teritory of North Sulawesi province. To maintain validity of collected data, several criterias being formulated for filtering invited respondents.

Samples taken must meet the following criteria: 1). Home Industry must have been established for a minimum of five years because this length of time is assumed to give sufficient time for delivery and introduction of home Industry innovation. 2). Home industry must have less than 5 employees (Indonesia statistic bureau or BPS). 3). Home industry are in the food and beverage manufacturing sector because these two is the mainstream industry in North Sulawesi province compare to others (BPS Sulut).

Unlike previous researches which is limited by only use cross sectional method. This research using longitudinal study because using two period of time. First period is phase one survey seeking the answer of hypothetis one, then there's an interval that being used for conducting training and skill also motivation to home industry in North Sulawesi province. After the interval, second phase survey conducted with the same questionnaire sheet. Training and skill tutorial being given to home industry are form of social service activity (Senduk 2011).

From 300 phase one survey invitations only 207 invitation attended and asked to fill in the provided questionnaire sheet. Then second phase survey sent to 207 invitation attended in phase one and only 123 attended. Data collection and compiling report also article writing in this research costs one and a half year, from March 2012 till August 2013.

Phase one questionnaire survey period filled by 207 attended invitation on April 2012. Then given interval of time during May 2012 period until December 2012. On January 2013, 207 respondent once again invited for attending training and skill tutorial in order to increase knowledge about business training and skill , eventhough only attended by 127 respondents. Then in May 2013 the whole 207 previous attended respondent invited again to fill in the same questionnaire again. However attendence only reach 123 invitations. June until August 2013 are data analysed period and reporting.

The data being analyzed using PLS-SEM. Eventhough correlation between variable within this research can be solved with other test such as binary regretion, but PLS-SEM capability in term of robust classic problem assumption and PLS-SEM being selected for this reason (Hair et al., 2011). Validity test using convergent method reflect on AVE (Average variance extracted) and for reliability test carried out with composite reliability method and cronbach alpha. Software being utilize on this research is SmartPLS 2.0. Accepted value in convergent validity test is AVE $\geq 0.5$ with extracted indicators to its variable (Hair et al., 2010). best value of cronbach alpha is $\geq 0.6$ (Nunnaly, 1978 dalam Hair et al, 2010) while best value of composite reliability is $\geq 0.7$ (Hair et al., 2010).

The first paragraph under each heading or subheading should be flush left, and subsequent paragraphs should have a five-space indentation. A colon is inserted before an equation is presented, but there is no punctuation following the equation. All equations are numbered and referred to in the text solely by a number enclosed in a round bracket (i.e., (3) reads as "equation 3"). Ensure that any miscellaneous numbering system you use in your paper cannot be confused with a reference [4] or an equation (3) designation.

\subsection{Measurement}

Questionnaire apply on this research adopted from previous research which is already translated and used for research carry out by Wuryaningrat (2012). However, the questionnaire had undergo a slight modification. The modification done by adding statement which consentrate on whether innovation had been perform being considered as new and different from closeby competitors. This modification considered necessity because generally home industry in Minahasa county and Manado city in cluster form and often have similar product and production process, even if there's a new produce but solely just immitating (Senduk, 2011). Detailed operational defininition and originial resource instrument of research can be cited in next section.

\subsection{Operational Definition}

Knowledge sharing defined as trading knowledge whether tacit or explicit to generate new knowledge (Van den Hoof and Ridder, 2004). There's two dimension of knowledge sharing which consist of knowledge donating dan knowledge collecting. Construction of knowledge sharing for knowledge donating dimension measured by six statement items while knowledge collecting by four statement items. Focus on this measurement is to be acquainted with knowledge sharing activeness in the company based on manager perception assessment.

Innovation capabilities defined as innovation as a form of latestness for competitive augment (Johannessen et al., 2001). There's six inner dimension consist of new product, new service, new production method, new market, new supply resources, and new sytem management. Innovation aptitude measured with six 
statement items developed by Johanessen et al. (2001). This measurement pointed out for displaying innovative level achieved by company.

Likert scale is used to quantify the acquired qualitative data, scale which range from 1 to 5 (1=rarely to $5=$ very often) and because there is modification of data, the instrument reassesment test became pertinent requirement. This test come in shape of input and opinion from several experts in entrepreneur and small bussiness sector from the university and cooperative Divison of middle small business and cooperative in Minahasa county. After it sufficiently acceptable, this instrument then ready for research usage.

\section{RESULTS}

\subsection{Respondents}

\subsubsection{Respondents Profile}

Data collection for respondent profile and business profile only conducted on phase one research. Description and respondent carried out to find out characteristics of respondent based on owner's profile or manager and business profile. From 207 home industry participate in this study, all originated from production sector or food and beverage manufacturer. Based on data in Table 4.1, most of $(73.9 \%)$ owner or manager of home industry participate in this research is male. the majority of then on mature length of age between 36-40 years old (51.21\%). Education level of owner or manager of home industry in this research sample mostly (43\%) High-school/equivalent. Level of education represent evidence of low categorized absorptive capacity. Vinding (2000) explain that level of education factor also became a determinant factor in absorptive capacity.

Table 4.1 Respondent Profile

\begin{tabular}{|c|l|c|c|}
\hline \multicolumn{1}{|c|}{ Category } & Number of Respondent & Percentage \\
\hline Dimension & \multicolumn{1}{|c|}{ (153 } & 73.9 \\
\hline \multirow{2}{*}{ Sex : } & a. Male & 54 & 26.0 \\
\hline & b. Female & 13 & 6.28 \\
Length of Age & a. $<25$ Years old & 12 & 11.11 \\
& b. 26-30 Years old & 23 & 51.21 \\
& c. 31-35 Years old & 106 & 25.60 \\
\hline & d. 36-40 Years old & 53 & 15.46 \\
Educational Level & e. $>40$ Years old & 32 & 14.98 \\
& a. Elementary & 31 & 43.00 \\
& b. Secondary & 89 & 1.45 \\
& c. High School & 3 & 25.12 \\
& d. Diploma & 52 & - \\
\hline
\end{tabular}

Source: processed primary data (2013)

\subsubsection{Business Profile}

Business profile in this research can be observe by business site, owned asset, and turnover of middle small business. Respondent business profile are sum up on table 4.2.

Tabel 4.2 Business Profile

\begin{tabular}{|c|c|c|c|}
\hline Dimension & Category & Number of Respondent & Percentage \\
\hline Location & $\begin{array}{l}\text { a. Rural } \\
\text { b.City }\end{array}$ & $\begin{array}{c}120 \\
87\end{array}$ & $\begin{array}{l}57.97 \\
42.02\end{array}$ \\
\hline Owned Asset (last 2 years) & $\begin{array}{l}\text { a. Less than } 5 \text { million } \\
\text { b. } 5 \text { million }-50 \text { million } \\
\text { c. }>50-100 \text { million } \\
\text { d. }>100-150 \text { million } \\
\text { e. }>150 \text { million }\end{array}$ & $\begin{array}{c}89 \\
97 \\
9 \\
10 \\
2\end{array}$ & $\begin{array}{l}43.00 \\
46.86 \\
4.35 \\
4.83 \\
0.97 \\
\end{array}$ \\
\hline $\begin{array}{l}\text { turnover } \\
\text { per month }\end{array}$ & $\begin{array}{l}\text { a. }<50 \text { million } \\
\text { b. }>50-100 \text { million } \\
\text { c. }>100-150 \text { million } \\
\text { d. }>150 \text { million }\end{array}$ & $\begin{array}{c}135 \\
53 \\
12 \\
7\end{array}$ & $\begin{array}{c}65.22 \\
25.60 \\
5.80 \\
3.38 \\
\end{array}$ \\
\hline
\end{tabular}

Source: processed primary data (2013)

From Table 4.2 it become obvious that business site from both rural and city are quite balanced eventhough most of it located in rural $(57.97 \%)$ and on the city side have $42.02 \%$ of home industry. This became possible because research location situated in Minahasa county and Manado city. Minahasa county represented by Tondano city and many rural area in that region while Manado city is a big city in North Sulawesi. Most of the respondents have asset in approximate value of 5 - 50 million rupiah (46.86\%) and less than 5 million rupiah as big as $43 \%$. While numbers of middle small business turnover per month on production sector in this sample were majority on number of 50 million rupiah $(65,22 \%)$. From approx turnover and respondent income can be categorized home industry as small scale business (See Act no.20 year 2008). 


\subsection{Instruments Validity and Reliability Testing}

After conducting face and content validity, the next step is convergent validity test to reinforce legality of research instrument. This convergent analysis being perform in order to obtain question item which can fulfill the requirement of good question item that accumulate into one variable (Hair et al., 2010). Because of this research consist of two phase, it's totally relevant convergent validity test also perform in same way (see previous section).

\subsubsection{Phase One: First Survey}

On the conducted phase one survey, 10 valid questionnaire item came out as result. In other words, the question of a total of 16 items have 6 items should be dropped . 6 items that must be dropped because the items did not reach the minimum value of factor loading of 0.5 or having problems cross loading. According to Hair et al . 2010 the value of the good is the factor loading $\geq 0.5$ and no problems of cross loading . 10 items left then managed to generate values that satisfy AVE rule of thumb of Hair et al . 2010 of $\geq 0.5$. In other words, convergent validity of the prism of AVE values are qualified. Similarly with the value of both composite reliability and Cronbach alpha reliability has been qualified. Composite reliability produce values $\geq 0.7$ (Hair et al . 2010) and Cronbach alpha generating value $\geq 0.6$ ( Nunnaly, 1978 in Hair et al ., 2010). Details validity and reliability of test results can be seen in Table 4.3.

Table 4.3. Test Validity and reliability: Phase one.

\begin{tabular}{|l|c|c|c|}
\hline \multicolumn{1}{|c|}{ VARIABLE } & AVE VALUE & $\begin{array}{c}\text { COMPOSITE } \\
\text { RELIABILITY }\end{array}$ & CRONBACH ALPHA \\
\hline Knowledge collecting (KC) & 0.670 & 0.859 & 0.764 \\
Knowledge donating (KD) & 0.517 & 0.808 & 0.708 \\
Innovation Capability (INOV) & 0.573 & 0.796 & 0.629 \\
\hline
\end{tabular}

Source: processed primary data (2013)

\subsubsection{The second stage: The second Survey}

In the survey conducted in the second phase of the resulting 13 valid questionnaire item. In other words, from a total of 16 items of questions there are 3 items should be dropped . Improvement with lessen dropped items should be an indication of a possible increase in knowledge or have experience with previous surveys . 3 items to be dropped because the items did not reach the minimum value of factor loading of 0.5 or having problems cross loading. According to Hair et al . 2010 the value of the good is the factor loading $\geq 0.5$ and no problems of cross loading . 10 items left then managed to generate values that satisfy AVE rule of thumb of Hair et al . 2010 of $\geq 0.5$. In other words, convergent validity of the prism of AVE values are qualified . Similarly with the value and reliability of both composite reliability alpha cronbcah had qualified . Composite reliability produce values $\geq 0.7$ ( Hair et al . 2010) and Cronbach alpha generating value $\geq 0.6$ ( Nunnaly, 1978 in Hair et al . 2010) . Details validity and reliability of test results can be seen in Table 4.4.

Table 4.4. Test Validity and Reliability Second Survey

\begin{tabular}{|l|c|c|c|}
\hline \multicolumn{1}{|c|}{ VARIABLE } & AVE VALUE & $\begin{array}{c}\text { COMPOSITE } \\
\text { RELIABILITY }\end{array}$ & CRONBACH ALPHA \\
\hline Knowledge collecting (KC) & 0.502 & 0.799 & 0.683 \\
Knowledge donating (KD) & 0.621 & 0.867 & 0.799 \\
Innovation Capability (INOV) & 0.521 & 0.843 & 0.771 \\
\hline
\end{tabular}

Source: processed primary data (2013)

\subsection{Hypotesis Testing}

Table 4.5. Hypothesis Testing

\begin{tabular}{|c|l|c|c|c|c|}
\hline Hypothesis & Relationship & Coefficient & S.E & T-stat & Condition \\
\hline Step 1 & KC $\rightarrow$ INOV & -0.204 & 0.161 & 1.271 & accepted \\
H1a & KD $\rightarrow$ INOV & 0.254 & 0,152 & 1.673 & \\
H1b & & & & \\
Step 2 & KC $\rightarrow$ INOV & 0.379 & 0.082 & 4.630 & accepted \\
H2a & KD $\rightarrow$ INOV & 0.200 & 0.077 & 2.601 & accepted \\
H2b & Note: sig. At the T - stat 5 \% two- tailed ( C.R = 1.960) \\
\hline
\end{tabular}

Source: processed primary data (2013)

In the first hypothesis, hypothesis $1 \mathrm{a}$ and $1 \mathrm{~b}$ can be said according to the allegations that have not been able to share their knowledge had a significant effect on the innovation capability of home industry in North Sulawesi province of Indonesia . It can be seen from the $t$ - stat is lower than 1.960 and 1.271 for hypothesis 1a $t$ 
- stat 1.673 lower than 1.960 for hypothesis $1 \mathrm{~b}$. Even in the beta coefficient (original sample ) values generated hypotheses 1a -0204 which means there is a negative effect, although not significant. In other words, collecting knowledge and knowledge Donating is a part of knowledge sharing has no effect on the ability of innovation survey conducted during the first phase .

Hypotheses $2 \mathrm{a}$ and $2 \mathrm{~b}$ are also in accordance with the allegations because the value of $\mathrm{t}$ - stat hypothesis $2 \mathrm{a}$ was 4,630 higher than 1.960 and $\mathrm{t}$ - stat for the hypothesis $2 \mathrm{~b} 2,601$ higher than 1,960. These results imply significantly positive effect occurs between knowledge collecting ( KC ) and knowledge Donating on innovation capability. In other words, collecting knowledge and knowledge Donating have a positive impact after two stage survey.

\section{CONCLUSION}

Knowledge sharing activity is an activity that is useful to gain new knowledge, where new knowledge is what can help improve the ability of innovation ( see Chapter II ). However, the new knowledge gained may take time to be understood. Weakness home industry that has been raised previously that may make knowledge sharing has not been able to have a significant influence. This result is contrary to the results of previous research that revealed many positive effects of knowledge sharing on innovation capability. However, the results of this study also confirms the results of Wuryaningrat research (2012) .

The learning process takes time. The learning process is carried out continuously is not possible to make the home business industry to be innovative. According to research from Wuryaningrat ( 2013) and Liao et al . (2006 ) conducted a knowledge sharing can increase the ability to absorb knowledge (absorptive capacity). Hence the provision of learning time and training and education plus provision for the home industry is needed. It is evident from this research that can answer that knowledge sharing has a positive impact on innovation capability when given the time and training for home industry. This research has confirmed the results of research that supports the positive impact that knowledge sharing on innovation capability (see the previous section).

This research result can also be interpreted to confirm the results of research which contradicts copy that has been described in the previous section. In other words, these two conflicting research results have the truth, and not something that needs to be debated. The entire results of previous research is correct, this has been proven by the results of this research. In conclusion, the results of this research confirmed that knowledge has become very vital for the sustainability of the business world in particular small -scale businesses, but the knowledge gained needs to be digested and understood. Knowledge necessary to understand the sufficient ability to absorb knowledge, which skills need to be developed in stages .

A conclusion section must be included and should indicate clearly the advantages, limitations, and possible applications of the paper. Although a conclusion may review the main points of the paper, do not replicate the abstract as the conclusion. A conclusion might elaborate on the importance of the work or suggest applications and extentions.

\section{RESEARCH LIMITATIONS AND SUGGESTIONS}

This research is a longitudinal study, but the time constraints of this kind of research can not be known. Research takes time and a half years of data collection may be not enough .

Selection of sampling method with convience sampling method is also a weakness in this research. Convenience sampling is likely to cause bias, although this possibility is reduced to trying to provide eligibility criteria can be selected to be the respondent.

The lapse of time between the delivery of training materials with a second survey fairly close together, so it is still possible imprint training materials. In other words, short intervals may not provide an opportunity for the home industry for their training practice in the daily effort that generated responses from respondents may have still imprinted training materials not as the result of training implementation.

Suggested further research for other researchers is to replicate this study in order to re- obtain a better external validity, with a time of research needs to be added. The addition of other variables such as absorptive capacity could make this research better.

\section{REFERENCES}

[1] Wuryaningrat, N.F. 2012. Knowledge sharing, absorptive capacity and Innovation Capabilities: Empirical Study on SMEs at Province Sulawesi Utara, Indonesia. Gadjah Mada International Journal of Business. 15: 61-77.

[2] Johannessen, J.A., B. Olsen, and G.T. Lumpkin. 2001. Innovation as newness: What is new, how new, and new to whom?. European Journal of Innovation Management 4: 20-31.

[3] Nonaka, I., G. Von Krogh and S. Voelpel. 2006. Organizational knowledge creation theory: evolutionary paths and future advances. Organization Studies, 27: 179-208.

[4] Du Plessis, M., 2007. The role of knowledge management in innovation. Journal of Knowledge Management, 11: 20-29.

[5] Darroch, J. 2005. Knowledge Management, innovation, and firm performance. Journal of Knowledge Management, 9: 101-115. 
[6] Davenport, T.H. and L. Prusak. 1998. Working Knowledge: How Organizations Manage What They Know. Harvard Business School Press, Boston, MA.

[7] Argote, L., B. McEvily, and R. Reagans. 2003. Managing knowledge in organizations: an integrative framework and review of emerging themes. Management Science 49: 571-82.

[8] Lin, H. 2007. Knowledge sharing and firm innovation capability: an empirical study. Journal of Manpower. 28: 315-332.

[9] Liao, S., W.C. Fei, and C.C. Chen. 2007. Knowledge sharing, absorptive capacity, and innovation capability: an empirical study of Taiwan's knowledge intensive industries. Journal of Information Science, 33: 340-359.

[10] Tidd, J. and J. Bessant, K.. (2005), Managing Innovation: Integrating Technological, Market and Organizational Change. Chichester: John Wiley \& Sons.

[11] Pirich, A., S. Knuckey, and J. Campbell. 2001. An interface between entrepreneurship and innovation: New Zealand SMEs perspective. DRUID Nelson and Winter Conference.

[12] Covin, J.G., and M.P. Miles. 1999. Corporate Entrepreneurship and the Pursuit of Competitive Advantage. Entrepreneurship: Theory and Practice 23: 105-120.

[13] Clark, K.B.\& Wheelwright, S.C. 1992. Managing New Product and Process Development. New York: Free Press.

[14] Lam, A., Lambermont-Ford. 2010, Knowledge sharing in organizational contexts: a motivation-based perspective. Journal of Knowledge Management 14: 51-66.

[15] Bartol, K.M. and A. Srivastava. 2002. Encouraging knowledge sharing: the role of organizational reward system. Journal of Leadership and Organizations Studies, 9: 64-76.

[16] Dyer, J.H, and K. Nobeoka. 2000. Creating and managing a high-performance knowledge sharing network: The Toyota case. Strategic Management Journal 21: 345-368.

[17] Indarti, N. 2010. The Effect of Knowledge Stickiness and Interaction on Absorptive Capacity: Evidence from furniture and software Small and Medium Enterprises in Indonesia. Disertasi (tidak dipublikasikan). Groningen: University of Groningen.

[18] Senduk, V. 2011. Observasi Kemampuan Inovasi Industri Rumah Tangga Kacang Kawangkoan Kabupaten Minahasa (Innovation Capabilities Observation at Kacang Kawangkoan Minahasa. Lembaga Penelitian (Research Institute). Unima

[19] Cooper, D.R., and P.S. Schindler. 2010. Business Research Methods (10 ${ }^{\text {th }}$ Edition). Singapore: McGraw-Hill.

[20] Senduk, V. 2013. Pelatihan dan Keterampilan Usaha Industri Makanan dan Minuman Rumah Tangga (Food and Beverage Home Industry Business Training). Lembaga Pengabdian Masyarakat (Society Institute), Unima.

[21] Hair, J.F, M. Sarstedt, C.M. Ringle, and J.A. Mena. 2011. An assessment of the use of partial least squares structural equation modeling in marketing research. Academic of Marketing Science, 10: 1-20.

[22] Hair, J.F., A.R.L., Tatham, and W.C., Black. 2010. Multivariate Data Analysis: Global Perspective (7 ${ }^{\text {th }}$ edition). New Jersey: Prentice Hall.

[23] Van den Hoof, B. and De Ridder, J. A. 2004. Knowledge sharing in context: the influence of organizational commitment, communication climate \& CMC use on knowledge sharing. Journal of Knowledge Management, Vol. 8, no. 6:117-130.

[24] Johannessen, J-A., Olaisen, J., and Olsen, B., 2001. Mismanagement of Tacit Knowledge: The Importance of Tacit Knowledge, The Danger of Information Technology, and What To Do About It. International Journal of Information Management. 21: 3-20. 